\title{
Study on the Influencing Factors and Consumer Behaviors of Bicycle Sharing in Beijing
}

\author{
Lijuan Wang ${ }^{1} \&$ Songbai Liu ${ }^{2}$ \\ ${ }^{1}$ City University of Macao, Macao, China \\ ${ }^{2}$ Zhuhai-HongKong-Macao Economic Research Institute, Beijing Normal University, Zhuhai, China \\ Correspondence: Prof. Dr. Songbai Liu, International Business Faculty, Beijing Normal University, Zhuhai, No. \\ 18 Jinfeng Rd. Zhuhai, Guangdong Province, China. E-mail: liusb@bnu.edu.cn
}

Received: November 2, 2018 Accepted: November 30, 2018 Online Published: January 11, 2019

doi:10.5539/ijms.v11n1p40 URL: https://doi.org/10.5539/ijms.v11n1p40

\begin{abstract}
This paper aims to explore the factors that affect consumer behavior in Beijing bicycle sharing. According to the questionnaire survey, perceived usefulness and perceived ease of use have positive impacts on consumer intentions. However, owing to the relatively high income of the sample population, the economic cost is also positively related to the intentions of consumers, and consumers' intentions are negatively related to actual behavior. This study provides a new contribution to the literature and a business opportunity. This study also provides a reference for market segmentation and the target population of the sharing economy.
\end{abstract}

Keywords: bicycle sharing, sharing economy, consumer behavior, TAM

\section{Introduction}

The "sharing economy" has very frequently been mentioned in recent years. The sharing economy influences different aspects of our economy today. In China, there are already several sharing economy platforms in all field of endeavor, such as traffic sharing (network car), bicycle sharing, house sharing, food and beverage sharing, logistics sharing, finance sharing, charge sharing and so on. "The sharing economy is a term for an emerging set of business models, platforms and exchanges" (Alen \& Berg, 2014).

The development of science and technology has various impacts on our daily life. At the same time, it brings much convenience to our daily lives. The emergence of bicycle sharing in China is a good example. Bike sharing is different from ride sharing (Towson, 2016). Big data-research (BDR) TM predicted that by the end of 2017, the total users in the whole country will reach 50 million, with an estimated growth of approximately $260 \%$. Bicycle sharing will continue to provide strong support for short-distance travel in urban traffic and solve the problem of the "last $1 \mathrm{~km}$ distance". As reported by the statistics from the Ministry of Transport of the People's Republic of China, in the peak period, there were approximately 70 bicycle sharing corporations in China, with more than 16 million bikes being ridden, and there were over 130 million registered users. By December 2017, there were still more than 30 companies remained in the bicycle sharing market.

The goal of this article is to investigate the factors that effect on consumer behavior in Beijing bike sharing. Firstly, we consider the age of the people who choose bicycle sharing. Secondly, we focus on how the perceived usefulness, perceived ease-of-use and perceived value affect the consumers' intentions. Finally, weanalyze the attributes of the consumers' intentions and how these affect the consumer's behavior. The results of this paper contribute to theory by updating the literature on the sharing economy and expose business opportunities for others to flourish in the sharing economy. This paper also contributes to the literature of consumers' behavior under the sharing economy. The research on the users' intentions as the starting point not only provides a reference for enterprises aiming to cultivate customer loyalty, but can also offer some guidance for the enterprises' strategic and operations management.

To analyze the relationship between the consumers' intentions and consumer's behavior, we take the following approaches. First, a questionnaire was designed to survey the users' backgrounds and attitudes about bicycle sharing, such as perceived usefulness, perceived ease-of-use and perceived value. The survey was distributed to people via the wjx.cn website. Because the focus of this study is the bicycle sharing users' behaviors in Beijing, the questionnaire was available in Chinese and a total of 115 surveys were completed in Beijing. 


\section{Literature}

\subsection{Sharing Economy}

When we mention the sharing economy, the words "collaborative consumption" will inevitably cross our mind. The term "collaborative consumption" was coined by Marcus and Joe (1978). They said: acts of collaborative consumption, namely, those events in which one or more persons consume economic goods or services in the process of engaging in joint activities with one or more others. Botsman and Rogers (2010) explained collaborative consumption in their book, noting: traditional sharing, haggling, loaning, dealing, leasing, gifting, and exchanging redefined through technology and peer centers. Collaborative Consumption (CC) consisted of: the peer-to-peer-based actions of obtaining, providing, or sharing goods and services, along with balanced supply and demand through online services. $\mathrm{CC}$ had been purported to relieve social problems, such as overconsumption, pollution, and shortages by reducing the expense of economic coordination within communities (Hamari, Sjöklint, \& Ukkonen, 2016).

However, some researchers thought the sharing economy provides new manners in which to supply products and services (Lăzăroiu, 2015a, b, c), as well as a chance to connect consumption, which depended on peer-to-peer junctions. The sharing economy consisted of buying and selling via peer-to-peer platform. Georgios, Davide and John revealed in their article that peer-to-peer markets, collectively known as the sharing economy, had emerged as alternative suppliers of goods and services traditionally provided by long-established industries (2017). Sharing economy companies had achieved great success all over the globe.

Parente, Geleilate, and Rong (2017) focused on internet companies that supply rent services for underutilized goods. In their research, they infered a strategic structure of what the service suppliers and customers thought from others studies, the mass media and interviews with the persons of trinity (service enabler-service provider-customer) in the sharing economy (Kumar, Lahiri, \& Dogan, 2017). McLaren and Agyeman (2015), Martin et al. (2015), and Chase (2015) gave a definition of the sharing economy as: improving efficiency and optimizing resources, thereby providing a platform for exchanges of merchandise and services between individuals and organized systems. Additionally, the researchers mentioned that the management models were democratic governance models, which brought together concepts of platform management, democratic organizational management and the playacting of values in social technical systems, offering an abstract structure for analyzing the rise of democratic standards of platform management (Martin, Upham, \& Klapper, 2017). Sustainability of sharing economy business models was another hot topic, and this article aimed to suggest a way to focus on and assess the sustainability of the sharing economy. To this end, we intended to discover major sustainability views by accepting circles of sustainability (Daunoriené, Drakšaite, Snieška, \& Valodkienè, 2015). Muñoz and Cohen (2017) put forward seven different dimensions of sharing business models: 1) platforms for cooperation, 2) underused resources, 3) peer-to-peer interplay, 4) joint governance, 5) mission-driven, 6) alternative funds, and 7) technology dependence. Parente, Geleilate, and Rong (2017) characterizeed sharing economy firms as possessing three features: 1 ) the business addresses the need to unlock the worth of unused or underutilized assets, 2) consumers pay for provisional use instead of proprietary use via an internet-based platform, 3) the business relies on $\mathrm{C} 2 \mathrm{C}$ interactions and network effects for growth.

With the sharing economy's development, scholars had created different disciplinary backgrounds related to the sharing economy, such as materialism and the sharing economy (Akbar, Mai, \& Hoffmann, 2016), the moral economy based on postmodern sociology (Germann, 2013), and access-based consumption based on neoclassical microeconomics (Bardhi \& Eckhardt, 2012). The conception of business platforms had been explored widely under the views of economic and practical management (Armstrong, 2006; Cusumano \& Gawer, 2002; Eisenmann et al., 2011; Evans, 2003; Gawer, 2009; Meyer \& Lehnerd, 1997; Parker \& Van, 2005).

In general, the sharing economy has the following features: 1) it reduces transaction costs, which can integrate idle social resources and information. 2) it is low-carbon, such as offering Uber services when you drive home from work by sharing the spare seat with other people and reducing the number of drivers on the road, while also making some extra money. 3) it supports sustainable development.

\subsection{Bicycle Sharing}

Boyd and Jan (2014) mentioned in their article that the first-generation of bicycle sharing, White Bikes, was an unsuccessful program that began in 1965. The company placed 50 unlocked white bikes to be shared all over Amsterdam, but the project failed because the bikes were repeatedly stolen or destroyed. The second-generation of bike sharing was first offered in Denmark in 1991 (DeMaio, 2009). As a coin-deposit system, it used recognizable bikes and appointed parking stations with locks (Shaheen, Guzman, \& Zhang, 2010). The third-generation bicycle sharing programs offered today are distinguished by four individual characteristics 
(Shaheen et al., 2010): recognizable bicycles, docking stations for security, kiosks for user interface, and advanced technology, such as radiofrequency identification (RFID) cards, for bike tracking and checkout.

In China, according to a report of Bigdata-Research (BDR), in the first quarter of 2017, the bicycle sharing market share was highly concentrated, with OFO and Mobike becoming a strong bicycle sharing due with relatively obvious advantages. OFO had 51.9\% market share, ranking first in the industry, while Mobike ranked second with $40.7 \%$ market share. Beijing was at the top of bicycle sharing list, and the development index was up to $90 \%$. (Note: The development index was calculated according to the basic level of the use of bicycle sharing, the development of environmental policy and the operation of the industry. Combined with the iMedia Research (IMR) statistical model, the higher the development index, the higher the maturity of bicycle sharing in the city.)

Bicycle Sharing (BS) was a new form of sharing economy, which was provided by enterprises on campuses and in subway stations, residential areas, business districts and public service areas. Currently, the national policy was in favor of the sharing economy: 1) The "13th Five-Year plan" first proposed "development of the sharing economy"; in 2016 the government released a report to "encourage the development of the sharing economy" and "support the development of sharing economy", marking the "sharing economy" and its representative business model as a national level of strategic planning. 2) Since March 1st, 2016, the green lifestyle had been advocated for in "Guidance on Promoting Green Consumption", which encouraged low-carbon travel such as walking, bicycling and using public transportation. 3) The government had introduced relevant policies to control the bicycle sharing.

From a public perspective, the emission of pollutants is becoming more serious with the increase of the urban use of motor vehicles. The desire for clean air is going much stronger, and green travel will become an inevitable trend. Traffic conjestion is also a major problem encountered in large and medium-sized cities of China. With the advancement of people's living conditions, the number of personal cars is growing so rapidly, and consequently traffic problems at rush hours are increasing severe. Bicycle sharing can effectively reduce traffic jams in the cities.

The related technology of bicycle sharing is relatively mature in China. In 2016, mobile phone users in China reached 700 million, up $12.1 \%$ from the previous year. With the fast growth of mobile Internet use, the maturity of GPS positioning technology, the convenience of mobile payment, the popularity of smart phones, and Internet access to the social credit system, a good foundation was laid for the penetration and development of bicycle sharing. The technical environment has been supportive in the following aspects: 1) GPS positioning technology provides support for users to find a dockless bicycle. 2) The popularity of smart phones provides users with a convenient terminal. 3) Mobile payment technology is mature and convenient, and the user experience is good. 4) Internet access to the social credit system reduces illegal vehicles and reduces the cost of enterprises.

The number of users sharing bicycles has been increasing rapidly since November 2016. The OFO official website shows that they were in more than 250 cities in 20 countries and had 200 million users by December 2017. The Mobike official website indicates that they are in more than 180 cities in 9 countries, have more than 7 million Mobike bicycles, provide intelligent tourism services for over than 200 million users all over the world, and their daily orders are over 30 million. The users of bicycle sharing are mainly concentrated in the first tier and second tier cities of China. Bicycle sharing companies are constantly emerging; meanwhile, there are also bankrupt companies. The market competition is intense. Bicycle Sharing is an effective solution to the "last mile" problem for commuters between the transport hub and the final destination.

In China, the research on bicycle sharing appears in the following areas: 1) bicycle sharing and the sharing economy (Qin \& Wang, 2017; He, 2017; Li, 2017; Wang, 2017; Lu, 2017). 2) Government responsibility — the government had no relevant policies about effective supervision of the mass packing and occupation of the road (Xie, 2017). Wang (2017) noted that the government should cooperate to create conditions for the development of bicycle sharing and promptly formulate a forward-looking standard for the management of bicycle sharing. 3 ) Cost management and profit model (Leng, 2017; Li, 2016; Wang, 2017; Zhou, 2017).

At present, other countries do not have such an extensive dockless bicycle sharing market as China. The bike sharing markets in other countries consist primarily of bikes that can be found and unloaded at self-serving docking stations. Fishman (2016) reviewed the literature of bike sharing, analyzes bike sharing history and recent growth, compares bike sharing user preference and sumed up the barriers to bike sharing: 1) convenience and safety concerns, 2) mandatory helmet legislation, and 3) sign-up process. Finally, he evaluateed the impacts of bike sharing.

According to the literature both domestic and global, the research about consumer behavior in China's bicycle 
sharing market still leave a gap.

\subsection{Technology Acceptance Model (TAM)}

In 1989, Davis (1989) proposed the TAM model (see Figure 1 below), which was used to explain and predict the use of computers in the workplace. TAM ((Davis, 1989; Davis et al., 1989) was dependent on the theory of reasoned action (TRA). Dishaw and Strong (1999) proved that attitude and behavior are extremely closely related, and the user's attitude about trying new technology can be described by two variables: perceived ease of use and perceived usefulness. After that, Serenko, and Bontis (2004) found that many researchers frequently used TAM to explain how major factors affect individuals' decisions to accept a new technology. However, it is necessary to modify the TAM model when it is used for research of the consumer rather than the company staff.

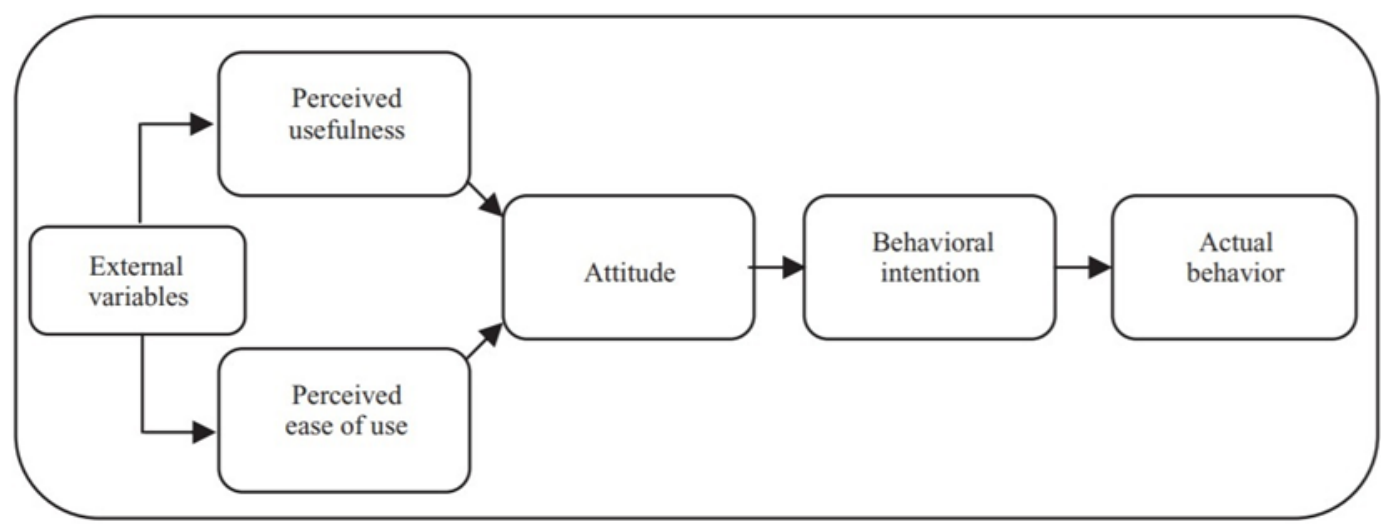

Figure 1. Technology Acceptance Model (TAM)

At present, TAM is not only applicable to technical acceptance but also to other factors. Lee and Lehto (2013) used the TAM model to investigate how users learn by YouTube. The willingness to accept YouTube was mainly influenced by perceived usefulness and user satisfaction. Chen, Liu, and Lin (2014) studied the desire to use the system of leaving or entering to school and increased the TAM model from the view of quality. Patwardhan, A. M. (2013) proposeed a cross-cultural and cross-national study to test the integrated model developed to explore consumer behavior, which might be influenced by national culture along with perceived risk. Research had also been conducted on the influencing factors of TAM-based tourism apps and use behavior (Li \& Zhang, 2015). The TAM model was also used to study users' perspectives and responses to social networking games. The study found that perceived mobility, perceived control, perceived enjoyment and perceived usefulness seriously affect users' willingness to use (Park, Baek, Ohm, \& Chang, 2014).

\section{Research Model and Hypothesis}

\subsection{Research Model}

The aim of this analysis was to find the user acceptance factors of bicycle sharing adoption in China. As argued, the research model offered in this article is given on the basis of the TAM model, which keeps the main structure of bicycle sharing customers' adoption behaviors cited in the literature (Zhang, 2017). Linked with the aspects of bicycle sharing, the model in this article brings forward three elements: perceived ease of use, perceived usefulness, and economic cost. Customers' behavior intentions, as a major index, forecast and clarify the customers' acceptance behaviors. The bicycle sharing user acceptance model is shown in Figure 2.

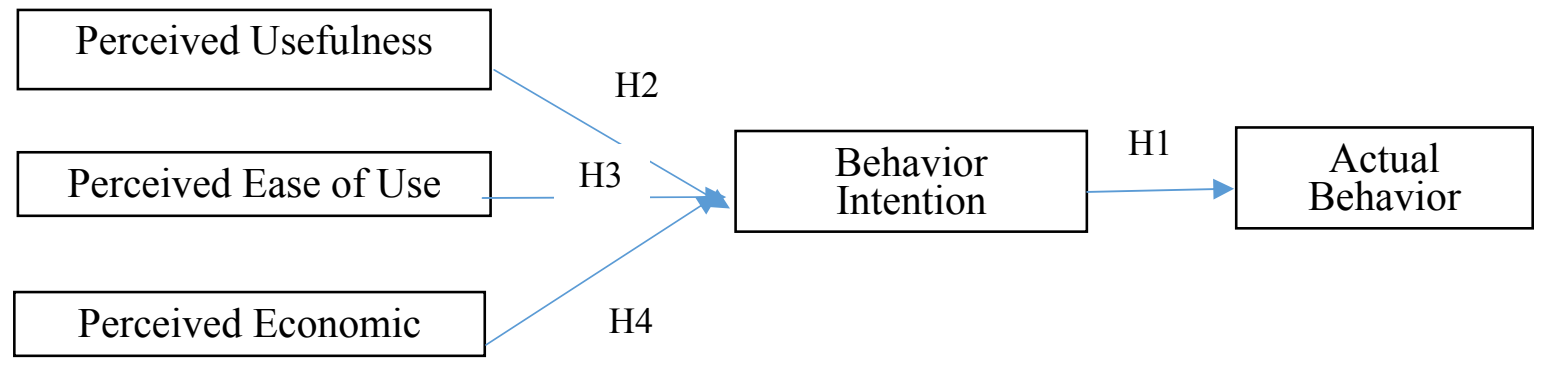

Figure 2. Conceptual framework 
This study aims to explore consumers' attitudes on the sharing economy and consumers' intentions, as well as their actual behavior under the sharing economy. This research is based on the development of bicycle sharing as an object of empirical research. The analysis of customer opinions and behavior is largely dependent on the theory of combination with reasoned action, planned behavior and the technology acceptance model. Furthermore this study uses the technology acceptance model as the foundation and links it with the unique attributes of bicycle sharing. Meanwhile it focuses on the user's perception and behavior related to bicycle sharing. The following are the details of the study (possible variables) and the proposed model (the connections between the variables).

\subsection{Research Variables and Hypotheses}

Most users choose to use bicycle sharing due to their own willingness, but certainly some peoplemake decision based on their causes. Fishbein and Ajzen (1975) think that, before consumers take some action, they will show a tendency, which we can use to predict the actual behavior of consumers when they tend to carry out this specific behavior, called behavioral intention. In subsequent studies on consumer behavior, many analyses have shown that behavioral intention is a precondition of behavior. For instance, in the technology adoption model proposed by Davis (1989), he used behavioral intention to calculate the real behavior of using new technology or information systems by individuals. Davis et al. then successfully used the model to forecast the customers' adoption of information technology. There are many researchers who, through empirical research, showed that consumer behavioral intention can accurately reflect the actual behavior of accepting various information systems (Wixom \& Todd, 2005), using blogs (Hsu \& Lin, 2008), e-shopping (Ha \& Stoel, 2009) and mobile banking (Luo, 2013). Therefore, this paper also uses behavioral intention to predict the actual behavior of users who use bicycle sharing. As a result, we propose the below hypothesis:

\section{H1: Behavior intention has a positive influence on actual behavior.}

Many researchers, such as Hu, Chau, Sheng, and Tam (1999), Lim, Xue, Yen et al. (2011), believe that the basic TAM model is one of the most outstanding models. The basic TAM model, shows a strong prediction ability, is widely applied to explore the acceptance of innovative technology in changing environments. TAMis established based on two assumptions. Firstly, "perceived usefulness" positively affects people's acceptance of a new technology. Secondly, "perceived ease of use" also has a positive impact on people's acceptance of this new technology. According the basic TAM assumptions, this study will propose another two hypotheses:

H2: Perceived usefulness has a positive influence on behavior intention.

H3: Perceived ease of use has a positive influence on behavior intention.

Any means of transportation will incur a certain fee. Ordinarily, the lower the cost, the better. Therefore, the users' perception of the cost will affect their intention to ride. Campbell et al. (2016) found that time and budget are among the most important factors that affect the public's choice of sharing bicycles when studying Beijing citizens' choice of sharing bicycles. Spending is essentially concerned with the cost of use. This article studies the user's perceived use cost (Casimir, Lee, \& Loon, 2012), and thus puts forward the following hypothesis:

H4: Perceived economic cost has a negative influence on behavior intention.

\section{Methods and Findings}

\subsection{Research Model}

Data were collected through convenience sampling. The sample of Beijing bicycle sharing was acquired on the WenJuanXing (WJX) website through sharing by the researchers' friends and colleagues. The questionnaires were collected from January 18, 2018 to January 31, 2018, and 11 of them are valid. The inquiries in this paper are outlined in two sections: the first consists of the figures of demographic description, including gender, age, and the favorite bicycle sharing brand; and the second section includes measures of all indices in the empirical model. To ensure the reliability and validity of the indices, this paper fully cites the formulations used in the relevant literature to develop the measurement variables on the basis of the characteristics of bicycle sharing, and the particular measurement of each variable and their sources are shown in Table 1. 
Table 1. Variable measures

\begin{tabular}{lll}
\hline Latent variable & The observed variables & Source \\
\hline Perceived & $\begin{array}{l}\text { using a bicycle sharing can save your trip time } \\
\text { using a bicycle sharing, you don't have to worry about losing your bike }\end{array}$ & Davis, (1989) \& self \\
& $\begin{array}{l}\text { using a bicycle sharing, you don't worry about maintaining of the bike. } \\
\text { using a bicycle sharing, you don't have to find a place for a fixed parking. }\end{array}$ & \\
\hline Perceived & you can find a bicycle sharing at any time & Zhang, (2017) \& self \\
ease of use & you can find a bicycle sharing at any place & \\
& you think it is convenient for APP of bicycle sharing & \\
& you think it is easy to operate the bicycle sharing & \\
& you think it is convenient for making payment & Jiang, Peng, \& Liu, (2015) \\
\hline Economic cost & you think the deposit of a bicycle sharing is very high & \& self \\
& you think the riding cost of a bicycle sharing is very high & \\
\hline you think the cost of bicycle sharing is higher than the cost of owning a bike & Zhang, (2017) \& self \\
& $\begin{array}{l}\text { if there is a bicycle sharing near your home (office), you would like to use it } \\
\text { you would recommend your favorite bicycle sharing brand to your classmates, }\end{array}$ & \\
\hline friends, and family members & would you like to use a bicycle sharing as usual & self \\
\hline
\end{tabular}

The elements were surveyed on a 7-point Likert scale. Actual behavior was measured by only two response options. To easily understand the questionnaire, we rehearsed a small-scale questionnaire before launching the large-scale questionnaire. Pre-test purposes were put forward to some professors in questionnaire form, requesting them to give advice about what they understood of the questionnaire items and their opinion of the grammar of expression. Finally, in accordance with the outcome and feedback from these interviews, the items from the earliest were adjusted to create the final questionnaire. The questionnaire was available in Chinese.

\subsection{Reliability and Validity Test}

To test the reliability and validity, this study used SPSS19 and Exps (a widget is used to count the validity). The results are shown below.

The Cronbach's alpha of perceived usefulness was 0.812 and the composite reliability CR was 0.8824 , indicating that the reliability was good. The AVE value is 0.6555 , which is greater than 0.5 , indicating good aggregation validity. (see the Table 2)

The Cronbach's alpha of perceived ease of use was 0.797 and the composite reliability was 0.8677 , indicating that the reliability was good. The AVE value is 0.5703 , which is greater than 0.5 , indicating good aggregation validity. (see the Table 2)

The Cronbach's alpha of economic cost was 0.586 and the composite reliability was 0.7813 , indicating that the reliability was good. The AVE value is 0.5497 , which is greater than 0.5 , indicating good aggregation validity. (see the Table 2)

The Cronbach's alpha of behavioral intention was 0.808 and the composite reliability was 0.8882 , indicating that the reliability was good. The AVE value is 0.7264 , which is greater than 0.5 , indicating good aggregation validity. (see the Table 2)

Table 2. Reliability and validity

\begin{tabular}{lllll}
\hline & Items (No) & Cronbach's alpha & AVE value & Composite reliability \\
\hline Perceived usefulness & 4 & .812 & .6555 & .8824 \\
Perceived ease of use & 5 & .797 & .5703 & .8677 \\
Economic cost & 3 & .586 & .5497 & .7813 \\
Behavior intention & 3 & .808 & .7264 & .8882 \\
\hline
\end{tabular}

\subsection{Findings}

This survey mainly studies the use and evaluation of bicycle sharing in Beijing. A total of 116 people participated in this survey, with women twice as many as men; nearly half of the respondents were between the ages of $35-45$, almost $38.8 \%$ of the respondents were between the ages of $25-34$, and only $12.9 \%$ of respondents 
were between the ages of 18-24; levels of disposable income were between 20,000 to 50,000 for $11.2 \%$ percent of respondents, between 10,000 to 20,000 for $28.4 \%$ of respondents, below 10,000 for $58.7 \%$ of respondents, and more than 50,000 for $1.7 \%$ of respondents. There are $89.7 \%$ of respondents using bicycle sharing, most of them use Mobike (67.2\%) and OFO (60.3\%), and most of them pay by WeChat (65.5\%) and Alipay (50.9\%). Nearly $87 \%$ of respondents said that bicycle sharing can save travel time, and nearly $90 \%$ of respondents said they enjoy not worrying about their bicycles lost or bicycle maintenance problems. About $83.6 \%$ of the respondents said that bicycle sharing can reduce the hassle of finding a parking place. Less than half of the respondents said they could find bike sharing anytime and anywhere, approximately $80 \%$ of respondents said the bike sharing app was easy to use, and nearly $90 \%$ of respondents said that bicycle sharing operation and payment is very convenient. Also, nearly $77.6 \%$ of the respondents said the bicycle sharing deposit is too high, less than $30 \%$ of the respondents said the cost of riding is high. More than $90 \%$ of respondents said that if bicycle sharing was available nearby, they would be glad to use it more often; almost $87.1 \%$ of the respondents are willing to recommend their favorite bicycle sharing service to friends and family members.

Table 3. Profiles of respondents

\begin{tabular}{lllll}
\hline Demographics & Level & Frequency & Percent (\%) & Valid Percent (\%) \\
\hline Gender & Male & 38 & 32.8 & 32.8 \\
& Female & 78 & 67.2 & 67.2 \\
Age & $18-24$ & 15 & 12.9 & 12.9 \\
& $25-34$ & 45 & 38.8 & 38.8 \\
Disposable income (RMB) & $35-45$ & 56 & 48.3 & 48.3 \\
& $<10,000$ & 68 & 58.7 & 58.7 \\
& $10,000-20,000$ & 33 & 28.4 & 28.4 \\
& $20,000-50,000$ & 13 & 11.2 & 11.2 \\
& $>50,000$ & 2 & 1.7 & 1.7 \\
\hline
\end{tabular}

The mean, standard deviation and correlations of perceived usefulness, perceived ease of use, economic cost and behavioral intention analysis are shown in Table 4. It is known from Table 4 that perceived usefulness is positively related to perceived ease of use $(\mathrm{r}=0.471, \mathrm{p}<0.001)$; perceived usefulness is positively related to behavior intention $(\mathrm{r}=0.571, \mathrm{p}<0.001)$; perceived ease of use is positively related to behavior intention $(\mathrm{r}=0.477$, $\mathrm{p}<0.001)$; economic cost is negatively related to behavior intention, but it's not significant $(\mathrm{r}=-0.011)$.

Table 4. Descriptive statistics and correlations in perceived usefulness, perceived ease of use, economic cost and behavior intention

\begin{tabular}{|c|c|c|c|c|c|c|c|}
\hline & & Mean & Std deviation & $\begin{array}{l}\text { Perceived } \\
\text { usefulness }\end{array}$ & $\begin{array}{l}\text { Perceived ease } \\
\text { of use }\end{array}$ & $\begin{array}{l}\text { Economic } \\
\text { cost }\end{array}$ & $\begin{array}{l}\text { Behavior } \\
\text { intention }\end{array}$ \\
\hline $\begin{array}{l}\text { Perceived } \\
\text { usefulness }\end{array}$ & Pearson correlation & 5.8168 & 1.20161 & 1 & & & \\
\hline $\begin{array}{l}\text { Perceived ease } \\
\text { of use }\end{array}$ & Pearson correlation & $4.9190 \mathrm{~d}$ & 1.09798 & $.471 ※ ※$ & 1 & & \\
\hline Economic cost & Pearson correlation & 4.0431 & 1.23204 & -.077 & .000 & 1 & \\
\hline $\begin{array}{l}\text { Behavior } \\
\text { intention }\end{array}$ & Pearson correlation & 5.8190 & .97147 & $.571 ※ ※$ & $.477 ※ ※$ & -.011 & 1 \\
\hline
\end{tabular}

Note. $※$ correlation is significant at the 0.01 level (2-tailed).

Table 5. Coefficients ${ }^{\mathrm{a}}$

\begin{tabular}{|c|c|c|c|c|c|c|}
\hline \multirow[b]{2}{*}{ Model } & & \multicolumn{2}{|c|}{ Unstandardized Coefficients } & \multirow{2}{*}{$\begin{array}{l}\text { Standardized Coefficients } \\
\text { Beta }\end{array}$} & \multirow[b]{2}{*}{$\mathrm{t}$} & \multirow[b]{2}{*}{ Sig. } \\
\hline & & $\mathrm{B}$ & Std. Error & & & \\
\hline \multirow[t]{2}{*}{1} & (Constant) & 3.134 & .369 & & 8.489 & .000 \\
\hline & Mean of perceived usefulness & .462 & .062 & .571 & 7.426 & .000 \\
\hline \multirow[t]{3}{*}{2} & (Constant) & 2.562 & .398 & & 6.442 & .000 \\
\hline & Mean of perceived usefulness & .360 & .068 & .445 & 5.303 & .000 \\
\hline & Mean of perceived ease of use & .237 & .074 & .268 & 3.193 & .002 \\
\hline
\end{tabular}

Note. ${ }^{\mathrm{a}}$. Dependent Variable: mean of behavior intention. 
Table 6. Model summary

\begin{tabular}{|c|c|c|c|c|c|c|c|c|c|}
\hline \multirow[b]{2}{*}{ Model } & \multirow[b]{2}{*}{$\mathrm{R}$} & \multirow[b]{2}{*}{ R Square } & \multirow[b]{2}{*}{ Adjusted R Square } & \multirow[b]{2}{*}{ Std. Error of the Estimate } & \multicolumn{5}{|l|}{ Change Statistics } \\
\hline & & & & & R Square Change & F Change & df1 & df2 & Sig. F Change \\
\hline 1 & $.571^{\mathrm{a}}$ & .326 & .320 & .80102 & .326 & 55.151 & 1 & 114 & .000 \\
\hline 2 & $.618^{\mathrm{b}}$ & .382 & .371 & .77055 & .056 & 10.192 & 1 & 113 & .002 \\
\hline
\end{tabular}

Table 7. ANOVA $^{\mathrm{c}}$

\begin{tabular}{lllllll}
\hline Model & & Sum of Squares & $\mathrm{df}$ & Mean Square & $\mathrm{F}$ & Sig. \\
\hline 1 & Regression & 35.386 & 1 & 35.386 & 55.151 & $.000^{\mathrm{a}}$ \\
& Residual & 73.145 & 114 & .642 & & \\
& Total & 108.532 & 115 & & & $.000^{\mathrm{b}}$ \\
\hline 2 & Regression & 41.438 & 2 & 20.719 & 34.895 & \\
& Residual & 67.094 & 113 & .594 & & \\
& Total & 108.532 & 115 & & & \\
\hline
\end{tabular}

Note. ${ }^{\text {a }}$. Predictors: (Constant), Mean of perceived usefulness.

b. Predictors: (Constant), Mean of perceived usefulness, Mean of perceived ease of use.

c . Dependent variable: (Constant), Mean of behavior intention.

As seen from Table 5 above, this study used stepwise regression analysis to explore the findings that perceived usefulness and perceived ease of use are significantly related with behavioral intention. $(\operatorname{sig}<0.05)$ Beta represents the coefficients of the variables in the regression equation.

Table 6 explains the goodness of fit with the model and observed values. The R square is close to 1, which explains that the model is good. The adjusted $\mathrm{R}$ square is more accurate than the $\mathrm{R}$ square. In this paper, the perceived usefulness is good (adjusted $\mathrm{R}$ square is 0.320 ), the total adjusted $\mathrm{R}$ square of perceived usefulness and the perceived ease of use is 0.371 , which means the two independent variables can explain $37.1 \%$ of the change in the dependent variable.

Table 7 shows the results of the ANOVA, which indicates the results of variance analysis. From the results, it can be seen that the sig value corresponding to the $\mathrm{F}$ value is less than 0.05 , so the regression equation is useful. That is to say, the relationship between the explained variables and the explaining variables in the model is significant.

Table 8. Independent sample t-test

\begin{tabular}{|c|c|c|c|c|c|c|c|c|}
\hline \multirow{2}{*}{$\begin{array}{l}\text { Do you have used } \\
\text { the bicycle sharing? }\end{array}$} & \multicolumn{4}{|c|}{ Group Statistics } & \multirow[b]{2}{*}{ Behavior intention } & \multicolumn{3}{|l|}{ T-test } \\
\hline & $\mathrm{N}$ & Mean & Std. Deviation & Std. Error Mean & & $\mathrm{F}$ & $\mathrm{T}$ & Sig \\
\hline Yes & 104 & 17.7885 & 2.51084 & .24621 & Equal variances assumed & 4.249 & 3.814 & .000 \\
\hline No & 12 & 14.5833 & 4.44069 & 1.28192 & Equal variances not assumed & & 2.455 & .031 \\
\hline
\end{tabular}

Table 8 explains the relationship between the behavioral intention and actual behavior. In this test, there are 104 people who have used bicycle sharing, and only 12 people who haven't used bicycle sharing. The results of the T-test, $\mathrm{p}<0.001$, indicate that behavioral intention has a positive influence on actual behavior.

Finally, we find that the hypotheses are supported, except that perceived economic cost has a negative influence on behavioral intention. There is low significance.

\section{Conclusion, Future Research and Limitations}

\subsection{Conclusion}

This study uses the empirical research method to examine the data, and the results are shown in below.

Table 9. The result of hypothesis

\begin{tabular}{ll}
\hline Hypothesis & Result \\
\hline H1: Behavior intention has a positive influence on actual behavior. & Support \\
H2: Perceived usefulness has a positive influence on behavior intention. & Support \\
H3: Perceived ease of use has a positive influence on behavior intention. & Support \\
H4: Perceived economic cost has a negative influence on behavior intention. & Rejected \\
\hline
\end{tabular}


It can be seen from the above table that one hypothesis is rejected. The research results are discussed below.

The age of the respondents is roughly $35-45$ years old. The proportion of the $25-45$ age group is almost $87 \%$. That is to say, the target respondents of this survey are those who have working experience and have some economic foundation. They usually commute in a private car or taxi, and whose probability of selecting public transportation is relatively low; however, some are willing to use bicycles and have an interest in the new sharing economy. In the results, the behavioral intention does not have a positive effect on the actual behavior, which agrees with the results of Big Data Research, according to which up to $70 \%$ of bicycle sharing users are approximately 25 years old.

The percentage of respondents with disposable income between 10000 and 50000 was as high as $70 \%$. For these people, the deposit required by OFO (199) or Mobike (299) is relatively cheap. Their intention to use bicycle sharing does not increase as economic cost decreased. From the perspective of behavioral economics, the reference point for individual decisions is not as obvious as that for those with lower income (such as college students).

Perceived usefulness and perceived ease of use have a positive effect on behavioral intention, and these results are consistent with the TAM theory. For a new technology or business model, no matter what age or income is, ease of use and practicality will positively affect customers.

\subsection{Managerial Implications}

The differences in age and income offer important managerial implications. With the increase of age and income, people's consumption behavior will tend toward something of high quality or something matching their social status, whereas young people prefer new, low-cost things. Given the low cost of bicycle sharing or other goods and services in the sharing economy, the target market should focus on young people or the lower income group. Managers or marketers should pay attention to the current subdivision and positioning strategies. There are different economic distributions throughout China, and in various regions there are significant differences in per capita GDP and disposable income (China Statistical Yearbook, 2017). Because income can urge on people's consumption, there is a need to segment the market according to the regional-level elements.

The findings also highlight that usefulness and ease of use have a positive effect on behavioral intention. The convenience of the bicycle sharing app is a significant factor. In the investigation, nearly $67.2 \%$ of respondents choose Mobike over OFO because in the beginning, Mobike's unlocking and positioning system was better than OFO's. In the process of actual use, the destruction rate of OFO bikes is higher than that of Mobike. Thus, OFO launched new bicycles into the market and updated their unlocking and positioning systems. As enterprises enter the new market, they should lay special stress on the usefulness and ease of use of their products.

\subsection{Limitation and Future Research}

This study examines the factors affecting behavioral intention of consumers to use bicycle sharing based on perceived usefulness, perceived ease of use, and economic cost. Behavioral intention affects actual behavior. The respondents of the survey are mainly 30-40 years old. However, the consequences should be explained carefully. If we can expand the group size and discuss different groups individually, the results of the model should be more meaningful. Firstly, the sample size consisting of Beijing bicycle sharing users is limited and may not completely symbolize their matching populations. Secondly, the general principle of the consequences is narrowly applicable to Beijing users. Thirdly, some possible moderators, such as environmental protection, attitude, subjective norms and psychological enjoyment were excluded in this paper. The possible moderating effects should be studied in the future. Considering that bicycle sharing and the sharing economy are hot topics, other sharing economic models are also worth further exploring.

In addition, the literature on bicycle sharing and the sharing economy is limited, and the sharing economy develops over in a short time. How to make an enterprise profitable or ensure that the enterprise continues to operate is also worth studying in-depth interview? For example, Uber, a representative of the sharing economy, is still in a state of loss.

\section{References}

Akbar, P., Mai, R., \& Hoffmann, S. (2016). When Do Materialistic Consumers Join Commercial Sharing Systems. Journal of Business Research, 69(10), 4215-4224. https://doi.org/10.1016/j.jbusres.2016.03.003

Alex, S. (2015). The Business of Sharing: Making It in The New Sharing Economy. Palgrave Macmillan. https://doi.org/10.1057/9781137376183

Allenm, D., \& Berg, C. (2014). The Sharing Economy: How Over-Regulation Could Destroy an Economic 
Revolution.

Armstrong, M. (2006). Competition in Two-Sided Markets. RAND J. Econ, 37(3), 668-691. https://doi.org/10.1111/J.1756-2171.2006.Tb00037.X.

Bardhi, F., \& Eckhardt, G. M. (2012). Access-Based Consumption: The Case of Carsharing. J. Consum. Res., 39(4), 881-898. https://doi.org/10.1086/666376

Botsman, R., \& Rogers, R. (2010). What's Mine Is Yours: The Rise of Collaborative Consumption. New York: Harper Business.

Campbell, A. A., Cherry, C. R., Ryerson, M. S., \& Yang, X. (2016). Factors Influencing the Choice of Shared Bicycles and Shared Electric Bikes in Beijing. Transportation Research Part C: Emerging Technologies, 67, 399-414. https://doi.org/10.1016/j.trc.2016.03.004

Casimir, G., Lee, K., \& Loon, M. (2012). Knowledge Sharing: Influences of Trust, Commitment and Cost. Journal of Knowledge Management, 16(5), 740-753. https://doi.org/10.1108/13673271211262781

Chase, R. (2015). Peers Inc: How People and Platforms Are Inventing the Collaborative Economy and Reinventing Capitalism. New York: Public Affairs.

Chen, T. L., Liu, H. K., \& Lin, A. M. (2014). Construct of Educational Information System's Using Willingness Model: An Extended Application of Technology Acceptance Model. International Journal of Organizational Innovation.

China Statistical Yearbook. (2017). Beijing, China: China Statistics Press.

Cohen, B. D., \& Kietzmann, J. (2014). Ride On! Mobility Business Models for The Sharing Economy. Organization \& Environment, 27(3), 279-296. https://doi.org/10.1177/1086026614546199

Cusumano, M. A., \& Gawer, A. (2002). The Elements of Platform Leadership. MIT Sloan Management, 43(3), $51-58$.

Daunorienè, A., Drakšaite, A., Snieška, V., \& Valodkienè, G. (2015). Evaluating Sustainability of Sharing Economy Business Models. Procedia-Social and Behavioral Sciences, 213, 836-841. https://doi.org/10.1016/j.sbspro.2015.11.486

Davis, F. D. (1989). Perceived Usefulness Perceived Ease of Use and User Acceptance of Information Technology. MIS Quarterly, 13(3), 319-340. https://doi.org/10.2307/249008.

Davis, F. D., Bagozzi, R. P., \& Warshaw, P. R. (1989). User Acceptance of Computer Technology: A Comparison of Two Theoretical Models. Management Science, 35(8), 982-1003. https://doi.org/10.1287/mnsc.35.8.982

Demaio, P. (2009). Bike-Sharing: History, Impacts, Models of Provision and Future. Journal of Transportation, 12(4), 41-56. https://doi.org/10.5038/2375-0901.12.4.3

Dishaw, M. T., \& Strong, D. M. (1999). Extending the Technology Acceptance Model. Information \& Management, 36(1), 9-21. https://doi.org/10.1016/S0378-7206(98)00101-3

Eisenmann, T., Parker, G., \& Van, A. M. (2011). Platform Envelopment. Strateg. Manag. J., 32(12), 1270-1285. https://doi.org/10.1002/smj.935

Evans. (2003). Some Empirical Aspects of Multi-Sided Platform Industries. Rev. Netw. Econ., 2(3), 191-209. https://doi.org/10.2202/1446-9022.1026

Felson, M., \& Joe, L. S. (1978). Community Structure and Collaborative Consumption: A Routine Activity Approach. American Behavioral Scientist, 21(March-April), 614-624. https://doi.org/10.1177/000276427802100411

Fishbein, M., \& Ajzen, I. (1975). Beliefs, Attitude, Intention, and Behavior. Reading MA, Addision-Wesley.

Fishman, E. (2016). Bikeshare: A Review of Recent Literature. Transport Reviews, 36(1), 92-113. https://doi.org/10.1177/000276427802100411

Gawer, A. (2009). Platforms, Markets and Innovation. Northampton, MA: Edward Elgar. https://doi.org/10.4337/9781849803311

Georgios, Z., Davide P., \& John, W. B. (2017). The Rise of The Sharing Economy: Estimating the Impact of Airbnb On the Hotel Industry. Journal of Marketing Research, 54(5), 687-705. https://doi.org/10.1509/jmr.15.0204

Germann, M. J. (2013). Social Networking Technologies and The Moral Economy of Alternative Tourism: The 
Case of Couchsurfing. Org. Ann. Tour. Res., 43, 210-230, https://doi.org/10.1016/J.Annals.2013.08.001

Ha, S., \& Stoel, L. (2009). Consumer E-Shopping Acceptance: Antecedents in A Technology Acceptance Model. Journal of Business Research, 62(5), 565-571. https://doi.org/10.1016/j.jbusres.2008.06.016

Hamari, J., Sjöklint, M., \& Ukkonen, A. (2016). The Sharing Economy: Why People Participate in Collaborative Consumption. Journal of The Association for Information Science and Technology, 67(9), 2047-2059. https://doi.org/10.1002/Asi.23552

He T. (2017). Discussion on Bikesharing Phenomenon and Sharing Economic Development. Research on Technical Economy and Management, 8, 99-104.

Hsu, C. L., \& Lin, J. C. C. (2008). Acceptance of Blog Usage: The Roles of Technology Acceptance. Social Influence and Knowledge Sharing Motivation. Information \& Management, 45(1), 65-74. https://doi.org/10.1016/j.im.2007.11.001

Hu, P. J., Chau, P. Y., Sheng, O. R. L., \& Tam, K. Y. (1999). Examining the Technology Acceptance Model Using Physician Acceptance of Telemedicine Technology. Journal of Management Information Systems, 16(2), 91-112. https://doi.org/10.1080/07421222.1999.11518247

Jiang, G., Peng, L., \& Liu, R. (2015). Mobile Game Adoption in China: The Role of Tam and Perceived Entertainment, Cost, Similarity and Brand Trust. International Journal of Hybrid Information Technology, 8. https://doi.org/10.14257/ijhit.2015.8.4.24

Kumar, V., Lahiri, A., \& Dogan, O. B. (2017). A Strategic Framework for A Profitable Business Model in The Sharing Economy. https://doi.org/10.1016/J.Indmarman.2017.08.021

Lee, D. Y., \& Lehto, M. R. (2013). User Acceptance of Youtube For Procedural Learning: An Extension of The Technology Acceptance Model. Computer \& Education, 61, 193-208. https://doi.org/10.1016/j.compedu.2012.10.001

Leng, B. B. (2017). Analysis on The PEST Model of Bicycle Sharing Industry. Marketing Management Review, 4, 150 .

Li, D., \& Zhang, L. X. (2015). Study on The Influencing Factors of TAM Tourism App and User Behavior. Travel Journal, 30(8), 26-34.

Li, J. (2017). Some Thoughts on Sharing Economy—Based on The Analysis of The Case of Bicycle Sharing. The Farmers Consultant, 12.

Li, L. F. (2016). In Case of Mobike Bicycle Sharing to Achieve Sustainable Profitability. Jiangsu Commercial Forum, 35, 110-111.

Lim, S., Xue, L., Yen, C. C., Chang, L., Chan, H. C., Tai, B. C., ... \& Choolani, M. (2011). A Study on Singaporean Women's Acceptance of Using Mobile Phones to Seek Health Information. International Journal of Medical Informatics, 80(12), 189-202. https://doi.org/10.1016/j.ijmedinf.2011.08.007

Lu, Y. Q. (2017). Is "Bicycle Sharing” A Sharing Economy. Chinese Advertising, 7, 72-73.

Luo, X. R. (2013). Research on Consumer Mobile Banking Service Adoption Based on Technology Acceptance Model. Doctoral Dissertation, Nanjing University Business School.

Martin, C. J., Upham, P., \& Budd, L. (2015). Commercial Orientation in Grassroots Social Innovation: Insights from The Sharing Economy. Ecol. Econ, 118(C), 240-251. https://doi.org/10.1016/j.ecolecon.2015.08.001

Martin, C. J., Upham, P., \& Klapper, R. (2017). Democratising Platform Governance in The Sharing Economy: An Analytical Framework and Initial Empirical Insights. https://doi.org/10.1016/J.Jclepro.2017.08.123

Mclaren, D., \& Agyeman, J. (2015). Sharing Cities: A Case for Truly Smart and Sustainable Cities. MIT Press.

Meyer, M. H., \& Lehnerd, A. P. (1997). The Power of Product Platforms: Building Value and Cost Leadership. New York: The Free Press.

Muñoz, P., \& Cohen, B. (2017). Mapping Out the Sharing Economy: A Configurational Approach to Sharing Business Modeling. Technological Forecasting and Social Change, 125, 21-37. https://doi.org/10.1016/J.Techfore.2017.03.035

Parente, R. C., Geleilate, J. M. G., \& Rong, K. (2017). The Sharing Economy Globalization Phenomenon: A Research Agenda. Journal of International Management. https://doi.org/10.1016/J.Intman.2017.10.001

Park, E., Baek, S., Ohm, J., \& Chang, H. J. (2014). Determinants of Player Acceptance of Mobile Social 
Network Games: An Application of Extended Technology Acceptance Model. Telematics and Informatics, 31, 3-15. https://doi.org/10.1016/j.tele.2013.07.001

Parker, G. G., \& Van, A. M. W. (2005). Two-Sided Network Effects: A Theory of Information Product Design. Manag. Sci, 51(10), 1494-1504. https://doi.org/10.1287/Mnsc.1050.0400.

Patwardhan, A. M. (2013). Consumers' Intention to Adopt Radically New Products: A Conceptual Model of Causal Cultural Explanation. Journal of Customer Behaviour, 12(2). https://doi.org/10.1362/147539213X13832198548490

PR Newswire. (2014). Homestay Is the Origin of Sharing Economy. Retrieved 2016-07-15.

Qin, Z., \& Wang, Q. (2017). The Three-Party Cooperative Mechanism of Sharing Economic Deduction: Example Bicycle Sharing. Reform, 5, 124-134.

Schor, J. B., \& Fitzmaurice, C. J. (2015). Collaborating and Connecting: The Emergence of The Sharing Economy. In L. Reisch \& J. Thogersen (Eds.), Handbook of Research on Sustainable Consumption (p. 410), Cheltenham, UK: Edward Elgar. https://doi.org/10.4337/9781783471270.00039

Serenko, A., \& Bontis, N. (2004). A Model of User Adoption of Mobile Portals. Quarterly Journal of Electronic Commerce, 4(1), 69-98.

Shaheen, S., Guzman, S., \& Zhang, H. (2010). Bikesharing In Europe, The Americas, And Asia: Past, Present, And Future. Transportation Research Record, 2143, 159-167. https://doi.org/10.3141/2143-20

Towson, J. (2016). Cycling or Hitching? Beijing Review, 59(45), 32-33.

Wang, G. R. (2017). Systematic Exploration of The Development of Bicycle Sharing. Journal of Chang'an University (SOCIAL SCIENCE EDITION), 19(2), 30-35.

Wang, J. G. (2017). Analysis of The Profit Model of Bicycle Sharing Under the Internet Sharing Economy. China Business \& Trade, 11, 147-148.

Wixom, B. H., \& Todd, P. A. (2005). A Theoretical Integration of User Satisfaction and Technology Acceptance. Information Systems Research, 16(1), 85-102. https://doi.org/10.1287/isre.1050.0042

Zhang, J. Y. (2017). Research on The Factors Affecting the Intention and Behavior of OFO Bicycle Sharing. Doctoral Dissertation, Central China Normal University.

Zhou, K. W. (2017). Analysis of Business Models in The Era of Sharing Economy-An Example of OFO Bicycle Sharing. Manager Journal, 3.

\section{Copyrights}

Copyright for this article is retained by the author, with first publication rights granted to the journal.

This is an open-access article distributed under the terms and conditions of the Creative Commons Attribution license (http://creativecommons.org/licenses/by/4.0/). 